\title{
PENGGUNAAN MODEL TIME TOKEN ARENDS DALAM MENINGKATKAN KETERAMPILAN BERBICARA PESERTA DIDIK PADA KELAS V DI MADRASAH IBTIDAIYAH 27 LAMASIUDUL
}

\author{
Fitria Suciana \\ Institut Agama Islam Negeri Palopo \\ Jl. Agatis Balandai Palopo \\ E-mail: fitria53suciana@gmail.com
}

\begin{abstract}
This research uses classroom action research. The purpose of this study is to improve students' speaking ability in the learning process by using the speaking media card. Implementation of this research is conducted three cycles, each sisklus lasted for two meetings. Subjects in this study were students class V Madrasah Ibtidaiyah 27 Lamasi, which amounted to 28 people. In this research used qualitative and quantitative data analysis techniques. Qualitative data were analyzed by qualitative descriptive analysis. While quantitative data is analyzed by using statistic in the form of mean calculation (mean). The results of this study indicate that the average score of students' speaking skills increases in each cycle. In the first cycle with an average score of 2.03, it increases in cycle II with an average value of 3.18, and increasing again in cycle III, whose average value is 3.75. The conclusion of this research is by using the time token arends model hence speaking skill of class V student Madrasah Ibtidaiyah 27 Lamasi can increase.
\end{abstract}

Keywords: Time Token Arends, Speech Skills

\begin{abstract}
Abstrak
Abstrak memuat uraian singkat mengenai masalah dan tujuan penelitian, metode yang digunakan, dan hasil penelitian. Ditulis dalam dua bahasa yakni Bahasa Inggris dan Bahasa Indonesia. Kata kunci perlu dicantumkan untuk menggambarkan ranah masalah yang diteliti dan istilah-istilah pokok yang mendasari pelaksanaan penelitian. Kata-kata kunci dapat berupa kata tunggal atau gabungan kata.
\end{abstract}

Kata Kunci,: Artikel, Isi, Format.

\section{PENDAHULUAN}

Berbicara adalah keterampilan menyampaikan pesan melelui bahasa lisan. Proses berbicara kepada orang lain terjadi akibat adanya kesenjangan informasi (Sunarti \& Subana, 2004:217). Setiap peserta didik harus dapat menguasai keterampilan berbicara, karena keterampilan berbicara merupakan salah satu keterampilan berbahasa yang diajarkan disekolah. Keterampilan berbicara bermanfaat untuk meningkatkan komunikasi lisan dengan baik. Komunikasi lisan adalah sarana dalam menyampaikan pesan berupa pikiran, gagasan dan perasaan dari satu orang ke orang lainnya (Rustan \& Subhan, 2018). Keterampilan berbicara juga dapat menunjang 


\section{4 | Fitria Suciana}

keterampilan berbahasa yang lainnya bahkan berperan penting dalam pembelajaran yang lain sehingga pembelajaran dapat berjalan dengan lancar dan kondusif (Septri Wahyuningrum, \& Retno Winarni, Matsuri, 2015:1). Dengan berbahasa peserta didik dapat meningkatkan kesadaran dirinya terhadap nilai-nilai keberbedaan dan keberagaman yang melekat pada kehidupan lokal. Dari beberapa pendapat tersebut dapat disimpulkan bahwa keterampilan berbicara adalah kemampuan seseorang dalam menyampaikan atau menyatakan maksud, ide, gagasan, pikiran, serta perasaan pada orang lain, yang berupa kata-kata, agar kominikasi menjadi lebih baik maka peserta didik perlu meningkatkan keterampilan berbicaranya dengan menggunakan model time token arends.

Ada dua faktor yang digunakan pada saat berbicara, yaitu faktor kebahasaan dan faktor nonkebahasaan. Faktor-faktor yang perlu diperhatikan adalah sebagai berikut: (1) faktor kebahasaan meliputi (a) ketepatan ucapan, (b) penempatan tekanan, nada, dan durasi yang sesuai, (c) pilihan kata (diksi), (d) ketepatan sasaran pembicaraan. Sedangkan (2) faktor nonkebahasaan meliputi (a) sikap yang wajar, tenang, dan tidak kaku, (b) pandangan harus diarahkan kepada lawan bicara, (c) kesediaan menghargai pendapat orang lain, (d) gerak gerik dan mimik yang tepat, (e) kenyaringan suara, (f) kelancaran, (g) penalaran, serta (h) penguasaan topik (Nur Widya Ichsani, Suryani, Siti Halidjah 2017:3). Berdasarkan uraian tersebut dapat diketahui bahwa faktor-faktor yang mempengaruhi kegiatan berbicara adalah faktor kebahasaan (linguitik) dan nonkebahasaan (nonlinguistik). Tujuan pendidikan nasional menurut Undang-Undang RI Nomor 20 Tahun 2003, tentang Sistem Pendidikan Nasional, Pasal 3, "Pendidikan nasional berfungsi mengembangkan kemampuan dan membentuk watak serta peradapan bangsa yang bermartabat dalam rangka mencerdaskan kehidupan bangsa, bertujuan untuk berkembangnya potensi peserta didik agar menjadi manusia yang beriman dan bertakwa kepada Tuhan Yang Maha Esa, berahlak mulia, sehat, berilmu, cakap, kreatif, mandiri, dan menjadi warga negara yang demokratis serta bertanggung jawab" (Departemen Pendidikan Nasional RI, 2006:9). Untuk itu guru dituntut untuk kreatif, agar peserta didik dapat mengembangkan potensi dirinya secara aktif, sehingga dalam melaksanakan prinsip penyelenggaraan pendidikan sesuai dengan tujuan pendidikan nasional yang telah ditetapkan oleh undang-undang.

Kata atau istilah pembelajaran dan penggunaannya masih tergolong baru, yang mulai populer sejak lahirnya Undang-Undang Sistem Pendidikan Nasional No. 20 tahun 2003. Menurut undang-undang ini, pembelajaran diartikan sebagai proses interaksi peserta didik dengan pendidik dan sumber

PiJIES: Pedagogik Journal of Islamic Elementary School 
belajar pada satu lingkungan belajar (Ahmad Susanto, 2016:19). Sedangkan menurut Benyamin S. Bloom dan D. Krathwohl memilah taksonomi pembelajaran dalam tiga kawasan, yakni Kognitif, afektif, dan psikomotor (Hamzah B. Uno, 2011:35). Dengan demikian, pembelajaran dapat membantu peserta didik agar dapat belajar dengan baik. Tujuan pembelajaran biasanya diarahkan pada salah satu kawasan taksonomi.

Ada tiga ciri khas yang tekandung dalam sistem pembelajaran, yaitu: 1) Rencana ialah penataan ketenagaan, material, dan prosedur, yang merupakan unsur-unsur sistem pembelajaran, dalam suatu rencana khusus. 2) Kesaling tergantungan, (interdependence), antara unsur-unsur sistem pembelajaran yang serasi dalam suatu keseluruhan. Tiap unsur bersifat esensial, masingmasing memberikan sumbangannya kepada sistem pembelajaran. 3) Tujuan, sistem pembelajaran mempunyai tujuan tertentu yang hendak dicapai (Oemar Hamalik, 2011:66). Sedangkan belajar adalah perubahan tingkah laku yang disebabkan oleh pelatihan dan pengalaman (Hasan Basri 2015:13). Belajar merupakan proses manusia untuk mencapai berbagai macam kompetensi, keterampilan, dan sikap. Belajar di mulai sejak manusia lahir sampai akhir hayat (Baharuddin, \& Esa Nur Wahyuni, 2015:13). Untuk itu manusia di wajibkan belajar untuk menambah ilmu mereka.

Model pembelajaran time token arends merupakan model pembelajaran yang bertujuan agar setiap anggota kelompok diskusi mendapatkan kesempatan untuk berbicara menyampaikan pendapat mereka. Pembelajaran ini merupakan struktur yang dapat digunakan untuk mengajarkan keterampilan sosial. Selain itu, juga dapat menghindari peserta didik mendominasi pembicaraan atau diam sama sekali (Zainal Aqib, 2015:33). Dengan memiliki keterampilan sosial, siswa dapat saling memahami satu sama lain sehingga siswa sadar atas kemampuan yang dimiliki. Kurangnya kepercayaan diri siswa menjadi sumber kurangnya semangat kompetitif siswa dalam berlajar (Rustan \& Bahru, 2018). Menurut Ahmad Widodo, model pembelajaran time token arends sangat tepat untuk pembelajaran struktur yang dapat digunakan untuk mengajarkan keterampilan sosial, untuk menghindari peserta didik mendominasi pembicaraan atau peserta didik diam sama sekali (Aris Shoimin, 2016:216). Strategi pembelajaran time token arends merupakan salah satu contoh kecil dari penerapan pembelajaran demokratis di sekolah, model ini digunakan untuk melatih dan mengembangkan keterampilan sosial, agar peserta didik tidak mendominasi pembicaraan atau peserta didik diam sama sekali (Miftahul Huda, 2013:239). Dari beberapa pendapat tersebut dapat diketahui bahwa model pembelajaran time token arends merupakan salah satu model 
pembelajaran yang dapat mengajarkan peserta didik untuk aktif berbicara di dalam proses pembelajaran dikelas.

Model time token arends termasuk dalam model pembelajaran kooperatif (cooperative learning). Pembelajaran koopratif (cooperative learning) merupakan sistem pengajaran yang memberi kesempatan kepada peserta didik untuk berkerja sama dengan sesama. Pembelajaran kooperatif dikenal dengan pembelajaran secara berkelompok (Tukiran Taniredja, \& Efi Miftah Faridli, Sri Hamianto, 2011:55). Pembelajaran kooperatif didefinisikan sebagai falsafah mengenai tanggung jawab pribadi dan sikap menghormati sesama. Peserta didik bertanggung jawab atas belajar mereka sendiri dan berusaha menemukan informasi untuk menjawab pertanyaan-pertanyaan yang dihadapkan pada mereka (Agus Supridjono 2014:54). Pembelajaran kooperatif adalah salah satu bentuk pembelajaran yang berdasarkan paham konstruktivisme. Pembelajaran kooperatif merupakan strategi belajar dengan sejumlah orang sebagai anggota kelompok kecil yang tingkat kemampuannya berbeda (Mohammad Jauhar 2011:52). Metode kerja kelompok atau bekerja dalam situasi kelompok mengandung pengertian bahwa peserta didik dalam satu kelas dipandang sebagai satu kesatuan (kelompok) tersendiri atau di bagi atas kelompok-kelompok kecil (Ahmad Sabri 2007:56). Dari beberapa pendapat tersebut dapat diketahui bahwa model pembelajaran kooperatif adalah model pembalajaran yang dilakukan dalam kelompok.

Kemampuan menyampaikan pendapat pada proses pembelajaran peserta didik kelas V di Madrasah Ibtidaiyah 27 Lamasi masih tergolong rendah. Hal ini, dapat diukur dari cara penyampaian pendapat yang masih terpotong-potong, tersendat-sendat, dan rangkaian kalimat yang masih acakacakan. Selain itu, keberanian peserta didik untuk mengungkapkan pendapat juga masih rendah, ketika guru meminta peserta didik untuk menyampaikan pendapat, tidak ada peserta didik yang berani mengacungkan tangan, mereka terkesan masih malu-malu untuk menyampaikan pendapatnya pada saat proses pembelajaran di kelas. Berdasar hasil penelitian diketahui bahwa penyebab dari permasalahan tersebut adalah penggunaan metode pembelajaran yang monoton dari guru, yaitu ceramah. Metode ini hanya menekankan keaktifan guru, sedang peserta didik hanya mendengar dan mencatat apa yang diterangkan guru. Peserta didik jarang diberi kesempatan untuk menyampaikan pendapat di depan teman-temannya sehingga peserta didik tidak terbiasa untuk menyampiakan gagasan, ide atau pendapatnya.

Berdasarkan masalah yang telah dijelaskan tersebut, maka diupayakan mencari solusi untuk mengatasi masalah yang dihadapi peserta didik agar PiJIES: Pedagogik Journal of Islamic Elementary School 
lebih terampil dan aktif dalam berbicara. Untuk itu peneliti memilih menggunakan metode kooperatif tipe time token arends. Time token arends merupakan salah satu model pembelajaran kooperatif yang digunakan untuk melatih keterampilan bersosialisasi dan berpartisipasi, yang berupa kupon berbicara selama kurang lebih 30 detik masing-masing orang. Peserta didik harus berbicara untuk dapat menghabiskan kupon tersebut. Tujuannya menghindari peserta didik yang mendominasi pembicaraan atau diam sama sekali. Diharapkan dengan menggunakan metode ini peserta didik dapat lebih aktif dan percaya diri dalam mengemukakan pendapatnya

\section{METODE PENELITIAN}

Pendekatan yang digunakan dalam penelitian ini yaitu pendekatan kombinasi. Pendekatan kombinasi adalah metode pendekatan penelitian yang menggabungkan atau menghubungkan metode penelitian kuantitatif dan kualitatif (Sugiono 2013:19). Jenis penelitian yang digunakan dalam penelitian ini yaitu penelitan tindakan kelas (PTK). Menurut Kemmis tahun 1988, penelitian tindakan kelas adalah suatu bentuk penelitian reflektif dan kolektif yang dilakukan oleh peneliti dalam situasi sosial untuk meningkatkan penalaran praktik sosial mereka (Wina sanjaya 2009:24). Penelitan tindakan kelas adalah sebagai bentuk kajian yang bersifat reflektif oleh pelaku tindakan, yang dilakukan untuk meningkatkan kemantapan rasional dari tindakan-tindakan mereka dalam melaksanakan tugas, memperdalam pemahaman terhadap tindakan-tindakan yang dilakukan itu, memperbaiki kondisi dimana praktek-praktek pembelajan tersebut dilakukan, serta dilakukan secara kolaboratif (Saminanto 2010:3). Dari beberapa pendapat tersebut PTK dapat diartikan sebagai upaya pemecahan masalah yang terjadi di kelas, dengan melihat kendala yang mempengaruhi dalam proses pembelajaran.

Penelitian tindakan kelas (PTK) ini dilaksanakan dalam tiga siklus, siklus pertama dilakukan dua kali tatap muka dalam pembelajaran dan siklus kedua juga dilakukan dua kali tatap muka dalam pembelajaran, lalu dilanjutkan dengan siklus ketiga dengan dua kali tatap muka, hingga diketahui adanya peningkatan keterampilan berbicara pada siswa. Adapun masing-masing siklus terdiri atas 4 tahapan, yaitu; 1) perencanaan (planning), 2) pelaksanaan (action), 3) observasi/pemantauan (observation), dan 4) refleksi (reflection). Hal ini sesuai dengan model penelitian yang peneliti pilih, yaitu dengan menggunakan model Kemmis dan Taggart (Suharsimin Arikunto 2014:16). Komponen tersebut akan terus berputar secara berurutan dari siklus I menjadi siklus II dan akan terus berputar menuju siklus berikutnya hingga tujuan yang diinginkan dapat dicapai. 


\section{PEMBAHASAN RUMUSAN}

\section{Hasil Penelitian}

Penerapan model pembelajaran time token arends pada kelas $\mathrm{V}$ di Madrasah Ibtidaiyah 27 Lamasi. Langkah-langkah dari model pembelajaran ini adalah sebagai berikut. Kondisikan kelas untuk melaksanakan diskusi (cooperative learning / CL); Tiap peserta didik diberi kupon berbicara dengan waktu \pm 30 detik; Bila telah selesai bicara kupon yang dipegang peserta didik diserahkan pada guru; Peserta didik yang telah habis kuponnya tidak boleh bicara lagi, yang masih pegang kupon harus bicara sampai kuponnya habis (Zainal Aqib 2015:33). Dengan demikian seluruh peserta didik mendapat kesempatan untuk mengungkapkan pendapatnya dengan menggunakan kupon atau kartu berbicara.

Melalui penggunaan model time token arends ini guru mampu meningkatkan keterampilan berbicara peserta didik kelas V di Madrasah Ibtidaiyah 27 Lamasi dalam menyampaikan pendapat. Penelitian ini di analisis dengan teknik analisis kualitatif dan kuantitatif, data kualitatif di analisis dengan mendeskripsikan hasil observasi dan hasil wawancara, ada dua cara untuk menstrukturkan hasil penelitian ini yaitu dengan berpegang pada fokus tertentu dalam wawancara, dan wawancara dipandu oleh beberapa pertanyaan atau pedoman wawancara (Noeng Muhadjir 2002:142). Sedangkan data kuantitatif dianalisis dengan menggunakan statistik dalam bentuk perhitungan rata-rata (mean) dengan rumus $\overline{\mathrm{x}}=\frac{\Sigma \mathrm{fx}}{\Sigma \mathrm{f}}$ (Boediono \& Wayan Koster 2001:57). Penelitian ini dilakukan di kelas V Madrasah Ibtidaiyah 27 Lamasi, yang beralamatkan di Jalan Masjid Raya, Kelurahan Lamasi, Kecamatan Lamasi, Kabupaten Luwu. Subjek dalam penelitian ini adalah peserta didik kelas V Madrasah Ibtidaiyah 27 Lamasi, yang berjumlah 28 orang, terdiri dari 11 orang laki-laki dan 17 orang perempuan. Kegiatan penelitian ini dilaksanakan dari 18 Juli sampai dengan 05 Agustus 2017 dengan 7 kali pertemuan.

Pada tahap siklus 1 diketahui bahwa nilai rata-rata dari keseluruhan aspek yang dinilai yaitu 2,03, di mana nilai rata-rata lafal 1,89, nilai rata-rata diksi 1,85 , nilai rata-rata kefasihan 2 , nilai rata-rata kosa kata 1,75, dan nilai rata-rata sikap 2,5. Dari data tersebut, dapat diketahui bahwa masih banyak peserta didik yang mendapat nilai rendah hal ini menunjukkan bahwa masih banyak peserta didik yang belum menguasai keterampilan berbicara. Berdasarkan hasil observasi diketehui bahwa interaksi peserta didik dengan guru 28,57\%, peserta didik dapat berinteraksi dengan baik dengan teman $42,85 \%$, peserta didik yang mampu berbicara dengan baik $26,78 \%$, keaktifan peserta didik dalam bertanya 19,64\%, dan disiplin kehadiran peserta didik PiJIES: Pedagogik Journal of Islamic Elementary School 
100\%. Dari data tersebut, diketahui masih banyaknya peserta didik yang malu bertanya pada guru dan peserta didik yang mampu berbicara dengan baik masih sangat rendah.

Hasil evaluasi yang telah dilakukan pada siklus I, keterampilan berbicara peserta didik sudah mulai ada peninggkatan dibandingkan dengan prasiklus, mereka sudah mampu mengungkapkan pendapatnya walaupun masih sangat kurang dalam komponen penilaian, mereka masih terkesan ragu dalam penyampaian pendapatnya, dan masih sulit dalam memilih kata. Akibatnya hasil rata-rata keterampilan berbicara peserta didik masih belum mencapai nilai ketuntasan belajar yaitu 3,5. Kesulitan peserta didik dalam memilih kata-kata yang tepat menjadi kekurangan dalam silus I ini. Untuk itulah perlu diadakannya perbaikan pada siklus II agar peserta didik dapat memilih kata-kata yang tepat dalam berbicara.

Pada tahap siklus II diketahui bahwa nilai rata-rata dari keseluruhan aspek yang dinilai yaitu 3,18, di mana nilai rata-rata lafal 3, nilai rata-rata diksi 3,17, nilai rata-rata kefasihan 3,17, nilai rata-rata kosa kata 3,14, dan nilai rata-rata sikap 3,46. Dari data tersebut, dapat diketahui bahwa keterampilan berbicara peserta didik sudah mulai meningkat dibandingkan dengan siklus I yang nilai rata-ratanya hanya 2,03. Berdasarkan hasil observasi diketehui bahwa interaksi peserta didik dengan guru 44,64\%, peserta didik dapat berinteraksi dengan baik dengan teman 58,92\%, peserta didik yang mampu berbicara dengan baik 53,57\%, keaktifan peserta didik dalam bertanya 42,85\%, dan disiplin kehadiran peserta didik 100\%. Dari data tersebut, diketahui adanya peningkatan pada peserta didik dalam proses pembelajaran.

Hasil evaluasi yang telah dilakukan pada siklus II, sudah mengalaimi peningkatan di bandingkan dengan nilai rata-rata siklus sebelumnya, akan tetapi dari hasil nilai rata-rata keterampilan berbicara peserta didik belum mencapai nilai ketuntasan belajar yaitu 3,5. Hal tersebut menunjukkan bahwa masih adanya kekurangan dalam silus II ini, yaitu kurangnya motivasi peserta didik dalam proses pembelajaran. Untuk itulah perlu di adakannya perbaikan pada siklus III agar peserta didik lebih termotivasi dalam proses pembelajaran dan mendapat nilai lebih tinggi.

Pada tahap siklus III diketahui bahwa nilai rata-rata dari keseluruhan aspek yang di nilai yaitu 3,75, di mana nilai rata-rata lafal 3,71, nilai rata-rata diksi 3,96, nilai rata-rata kefasihan 3,85, nilai rata-rata kosa kata 3,53, dan nilai rata-rata sikap 3,25. Dari data tersebut pula dapat diketahui bahwa keterampilan berbicara peserta didik semakin meningkat dibandingkan dengan siklus I yang nilai rata-ratanya hanya 2,03 dan siklus II yang nilai 
rata-ratanya 3,18. Berdasarkan hasil observasi diketehui bahwa interaksi peserta didik dengan guru 78,57\%, siswa dapat berinteraksi dengan baik dengan teman 78,57\%, peserta didik yang mampu berbicara dengan baik $85,71 \%$, keaktifan peserta didik dalam bertanya 78,57\%, dan disiplin kehadiran peserta didik 100\%. Dari data tersebut diketahui bahwa peningkatan pada peserta didik dalam proses pembelajaran semakin baik.

Hasil evaluasi yang telah dilakukan pada siklus III, keterampilan berbicara peserta didik sudah semakin meningkat, dan dari hasil nilai ratarata keterampilan berbicara peserta didik sudah mencapai nilai ketuntasan belajar yaitu 3,5. Kekurangan pada siklus-siklus sebelumnya dapat teratasi dan hasil yang di inginkan telah tercapai. Para peserta didik sudah mampu meningkatkan kemampuan berbicara dan tidak merasa canggung lagi.

Diagram Peningkatan Nilai Rata-Rata Tiap Siklus

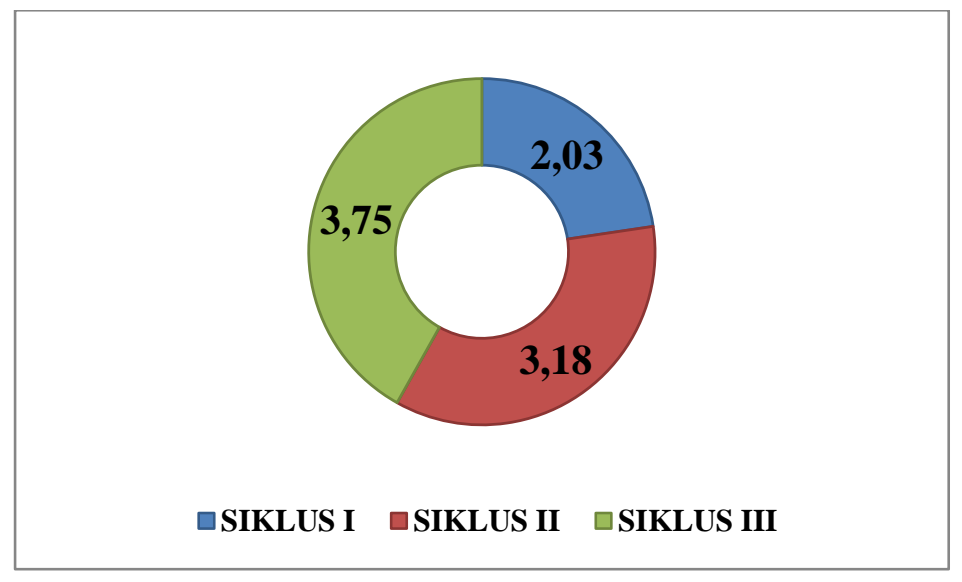

Diagram tersebut menjukkan bahwa, nilai rata-rata keterampilan berbicara peserta didik meningkat pada tiap siklusnya. Pada siklus I yang nilai rata-ratanya 2,03, meningkat pada siklus II yang nilai rata-ratanya 3,18, dan semakin meningkat lagi pada siklus III yang nilai rata-ratanya 3,75. Dengan demikian, dapat diketahui bahwa dengan penggunaan model pembelajaran time token arends maka keterampilan berbicara peserta didik dapat meningkat.

\section{Pembahasan}

Dari uraian tiap siklus tersebut dapat diketahui bahwa dalam setiap siklus terlihat ada peningkatan keterampilan berbicara dibandingkan pada siklus sebelumnya. Dengan penggunaan model pembelajaran time token arends keterampilan berbicara peserta didik kelas V Madrasah Ibtidaiyah 27

PiJIES: Pedagogik Journal of Islamic Elementary School 
Lamasi dapat meningkat. Untuk meningkatkan keterampilan berbicara peserta didik, selain menggunakan model pembelajaran time token arends, peneliti juga menggunakan berbagai cara dalam pelaksanaan pembelajaran keterampilan berbicara seperti memberi pekerjaan rumah dan memberi motivasi berupa hadiah pada peserta didik. Hal ini sejalan dengan teori reinforcement yang dikemukakan oleh Thorndike dengan law of effeck-nya yakni bahwa belajar dibantu, bila binatang percobaan memperoleh suatu kepuasan dengan kegiatannya, misalnya memperoleh makanan atau bentuk hadiah lainnya. Hadiah itu me-reinforce hubungan antara stimulus dan respon. Dalam teori Skiner reinforcement tidak merupakan hadiah atau reward melaikan berkat cotingency, yakni bila suatu respon langsung didahului oleh suatu stimulus. Seterusnya respon itu dapat pula berfungsi sebagai stimulus bagi respon berikutnya. Bagi Skiner reinforcement tidak berupa ganjaran atau kepuasan, akan tetapi hubungan yang erat dengan hal tertentu (Nasution, 2009:135).

Peneliti ini dilakukan sebagai upaya untuk meningkatkan keterampilan berbicara pada peserta didik kelas V Madrasah Ibtidaiyah 27 Lamasi dengan menggunakan model time token arends, dalam proses pembelajaran, nilai peserta didik semakin meningkat pada tiap siklusnya, karena dalam proses belajar peneliti menerapkan model pembelajaran time token arends untuk meningkatkan keaktifan berbicara peserta didik. Model pembelajaran time token arends ini diulang terus menerus tiap siklusnya. Hal ini sesuai dengan pendapat Skinner yang mengatakan bahwa belajar adalah suatu perilaku. Pada saat orang belajar, maka responya menjadi lebih baik sebaliknya, bila ia tidak belajar maka responya menurun (Dimyati Mudjiono 2006:9). Adapun yang digunakan peneliti selain menggunakan model time token arends untuk meningkatkan keaktifan keterampilan berbicara peserta didik yaitu dengan memberikan motivasi berupa kata-kata penyemangat dan hadiah agar peserta didik aktif dalam proses pembelajaran. Hal ini sejalan dengan teori yang dikemukakan oleh Maslow yang mengatakan bahwa tingka laku manusia dibangkitkan dan diarahkan oleh kebutuhan-kebutuhan tertentu. (Slameto, 2013:17). Pemberian motivasi dapat menstimulus peningkatan efikasi diri siswa terhadap kemampuan yang dimilikinya sehingga siswa mampu menyelesaikan tugas yang diberikan (Thaha \& Rustan, 2017).

Setelah mengunakan model pembelajaran time token arends tingkat keterampilan berbicara peserta didik kelas V Madrasah Ibtidaiyah 27 Lamasi bertahap meningkat yang dimana nilai pada siklus I yang nilai rata-ratanya 2,03, meningkat pada siklus II yang nilai rata-ratanya 3,18 , dan semakin meningkat lagi pada siklus III yang nilai rata-ratanya 3,75. Hal ini menunjukan bahwa, menggunakan model pembelajaran time token arends 
salah satu model pembelajaran yang baik, dan mampu meningkatkan keterampilan berbicara peserta didik dan proses pembelajaran.

\section{PENUTUP}

Hasil akhir dari penelitian ini menunjukkan bahwa penerapan model time token dalam proses pembelajaran dapat meningkatkan kompetensi peserta didik dalam keterampilan berbicara, dengan menggunakan media kartu berbicara. Pelaksanaan pembelajaran dengan menggunakan media kartu berbicara ternyata memberi pengaruh positif terhadap peningkatan keterampilan berbicara peserta didik. Model time token arends merupakan model yang sangat efektif dan layak digunakan sebagai rujukan untuk meningkatkan keterampilan berbicara peserta didik.

Adapun saran yang diberikan dalam penelitian ini: (1) Kiranya guru mampu melanjutkan penerapan model pembelajaran time token arends dalam pembelajaran, sehingga keterampilan berbicara peserta didik akan terus semakin meningkat. Selain itu, guru diharapkan mampu menambah dan membuat variasi yang lebih baik dalam model pembelajaran time token arends, agar peserta didik aktif dalam proses pembelajaran; (2) Bagi peserta didik, peserta didik perlu berlatih berbicara untuk menambah perbendaharaan kata sehingga dapat berkomunikasi dengan lancar, baik, dan benar. Peserta didik juga perlu mengembangkan keterampilan berbicara atas dasar pemahaman.

\section{DAFTAR PUSTAKA}

Arikunto, Suharsimin, \& Suhardjono, Supardi. 2011. Penelitian Tindakan Kelas, Jakarta: Bumi Aksara.

Aqib, Zainal. 2015. Model-model Media, dan Strategi Pembelajaran Kontekstual, Bandung: Yrama Widya.

Baharuddin, \& Esa Nur Wahyuni. 2015. Teori Belajar dan Pembelajaran, Jogjakarta: Ar-Ruzz Media.

Basri, Hasan. 2015. Paradigma Baru Sistem Pembelajaran, Bandung: Pustaka Setia.

Boediono \& Wayan Koster. 2001. Statistika dan Probabilitas, Bandung: Remaja Rosdakarya.

Departemen Pendidikan Nasional RI. 2006. Undang-Undang RI No 20 Tahun 2003, Tentang Sistem Pendidikan Nasional, Jakarta: Balai Pustaka.

PiJIES: Pedagogik Journal of Islamic Elementary School 
Hamalik, Oemar. 2011. Kurikulum dan Pembelajaran, Jakarta: Bumi Aksara.

Huda, Miftahul. 2013. Model-model Pengajaran dan Pembelajaran, Bandung: Pustaka Pelajar.

Ichsani, Nur Widya \& Suryani, Siti Halidjah. 2017. "Peningkatan Kemampuan Berbicara Dengan Menerapkan Model Pembelajaran Kooperatif Time Token Arends di Sekolah Dasar", (On Line) http://jurnal.utan.ac.id/index.php/JPDPB/ article/view/5935.

Jauhar, Mohammad. 2011. Implementasi Paikem dari Behavioristik Sampai Kontuktivistik, Jakarta: Prestasi Pustakarya.

Mudjiono, Dimyati. 2006. Belajar dan Pembelajaran, Jakarta: PT Rineka Cipta.

Muhadjir, Noeng. 2002. Metodologi Penelitian Kualitatif, Yogyakarta: Rake Sarasin.

Nasution. 2009. Berbagai Pendekatan dalam Proses Belajar dan Mengajar, Jakarta: Bumi Aksara.

Rustan, E., \& Bahru, M. S. (2018). Penguatan Self Confidence dalam Pembelajaran Matematika melalui Metode Suggestopedia. AlKhwarizmi: Jurnal Pendidikan Matematika Dan Ilmu Pengetahuan Alam, 6(1), 1-14.

Rustan, E., \& Subhan. (2018). Komunikasi Verbal Anak Pesisir Usia 7-8 Tahun Pada Transakasi Penjualan Produk Kebudayaan Dengan Turis mancanegara. Jurnal Pendidikan Usia Dini, 12(1), 12-28. https://doi.org/10.21009/JPUD.121 02

Sabri, Ahmad. 2007. Strategi Belajar Mengajar \& Micro Teaching, Bandung, Ciputat Press.

Sanjaya, Wina. 2009. Penelitian Tindakan Kelas, Jakarta: Kencana Prenada Media Group.

Saminanto. 2010. Ayo Praktik PTK, Semarang: Media Group.

Shoimin, Aris. 2016. 68 Model Pembelajaran Inovatif dalam Kurikulum 2013, Jogjakarta: Ar-Ruzz Media.

Slameto. 2013. Belajar dan Faktor-faktor yang Mempengaruhi, Jakarta: Rineka Cipta.

Subana \& Sunarti. 2004. Strategi Belajar Mengajar Bahasa Indonesia Bandung: Pustaka Setia.

Sugiono. 2013. Metode Penelitian Kombinasi, Bandung:Alfabeta.

Suprijono, Agus. 2014. Cooperative Learning Yogyakarta: Pustaka Pelajar.

Susanto, Ahmad. 2016. Teori Belajar dan Pembelajaran di Sekolah Dasar, Jakarta:Prenadamedia Group. 
Taniredja, Tukiran, \& Efi Miftah Faridli, Sri Hamianto. 2011. Model-model Pembelajaran Inovatif Bandung: Alfa Beta.

Thaha, H., \& Rustan, E. (2017). Orientasi Religiusitas dan Efikasi Diri dalam Hubungannya dengan Kebermaknaan Pendidikan Agama Islam pada Mahasiswa IAIN Palopo. Studi Agama Dan Masyarakat, 13(2), 163-179. https://doi.org/10.23971/jsam.v13i2.551

Uno, Hamzah B. 2011. Perencanaan Pembelajaran, Jakarta: Bumi Aksara.

Wahyuningrum, Septri, \& Retno Winarni, Matsuri. 2017." Peningkatan Keterampilan Berbicara Dengan Menggunakan Model Pembelajaran Kooperatif Tipe Time Token", (On Line) http:// jurnal.ftkip.uns.ac.id/index.php/pgsdsolo/ article/view/6243. 